\title{
Neuropsychological analysis of the features of mental development in school age children with mild perinatal hypoxic damage of the nervous system in their anamnesis
}

\author{
Alfiya S. Sultanova \\ Institute for the study of Childhood, Family and Education of Russian Academy of Education, \\ Moscow, Russia
}

Corresponding author. E-mail: alfiya_sultanova@mail.ru

Background. Perinatal pathology of the nervous system (PPNS) of hypoxic genesis is one of the most significant causes of deviations in mental development. It is necessary to investigate the impact of mild PPNS for the child's mental ontogenesis, because coarser perinatal lesions, as a rule, lead to significant violations of development and should be analyzed separately. From our point of view, the qualitative neuropsychological syndromic analysis adopted in Russian child neuropsychology is the most productive way to study this problem.

Objective. The purpose of this study was to conduct neuropsychological analysis of the features of mental development of school-age children with mild hypoxic PPNS in their anamnesis.

Design. Our research involved 62 children 10-12.5 years old, who were studying in comprehensive schools in Moscow. The main group was comprised of 42 neurologically healthy children who had hypoxic-ischemic encephalopathy of mild severity in their anamnesis. The control group was comprised of 20 neurologically healthy children without indication of pathology of pregnancy and labor in their anamnesis.

Methods. We used neuropsychological Luria tests that have been adapted for children, conducted an interview of parents and teachers about the peculiarities of children's behavior, and analyzed electroencephalogram reports.

Results. Every child with PPNS exhibited similar features, such as neurodynamic disorders and a lack of voluntary control. We called this symptom complex "subcorticalfrontal" neuropsychological syndrome. In addition, each child in the main group had a failure of at least one neuropsychological factor. The following functions showed insufficiency most often: voluntary attention, speech development, verbal-auditory memory, kinetic and kinesthetic praxis, visual-spatial gnosis, and phonemic hearing. Left hemisphere functions and interhemispheric interaction suffered to a greater degree. The children with PPNS were divided into two subgroups, depending on the severity of the insufficiency of executive functions (EF). Children with severe insufficiency of EF more 
frequently demonstrated violation of development of verbal-logical thinking, difficulties in social adaptation, emotional disorders, and deviant behavior.

Conclusion. The mental development of school-age children with mild PPNS in their anamnesis differs from the development of their peers. We can talk about the longterm consequences of mild hypoxic perinatal damage of the nervous system.

Abbreviations. PPNS - perinatal pathology of the nervous system; CNS - central nervous system; EEG - electroencephalogram; EF - executive functions.

Keywords: perinatal hypoxic damage of the nervous system; child neuropsychology; cultural-historical concept; neuropsychological analysis; school-age children.

\section{Introduction}

At present, many specialists who work with children and adolescents (psychologists, educators, defectologists, etc.) note that the mental development of children today shows a number of significant differences from that observed several decades ago. Perhaps only "cabinet scientists", who do not have the practical experience of interaction with children in actual conditions, can't see that today the "psychological portrait" of a child at different age levels differs from that described in the "classical" psychological and pedagogical literature. "The child did not become worse or better than his peer of twenty years ago; he just became different" (Feldshtein, 2010, p. 6). Most likely, the general patterns of mental ontogeny, the vectors of development, remain unchanged. However, the meaningfulness of the stages of development, the formation of behavior and the cognitive-operational sphere, and the formation of the child's and his/her social connections, have undergone significant changes.

From the cultural-historical point of view, which is fundamental to Russian psychology, this is to be expected: the child's mental ontogeny is largely determined by the social situation of development (Vygotsky, 1984), which has changed significantly over the past decades (Sultanova \& Ivanova, 2010). The social situation of development is a special combination of internal development processes and external conditions, typical for each age level (Bozhovich, 2008).

At present, both major components of the social situation of development have been modified. First of all, there are the external conditions: over recent decades, rapid changes in all spheres of human life have occurred in our country (as well as all over the world). Economic, political, and socio-cultural modifications have led, in particular, to transformation of the patterns of family formation, marriage, and the conditions of family upbringing, as well as changes in the information environment, changes in the sphere of education, and modification of children's ways of life.

The internal components of the social situation of development have also changed. First of all, there is the state of children's neuropsychiatric and somatic health. The prevalence of basic forms of children's mental illnesses grows by 10 $15 \%$ every ten years; neuro-mental illnesses cause child incapacity in $70 \%$ of these cases (Feldshtein, 2010). Specialists assume that over $80 \%$ of children now need some psychological, psychotherapeutic, or psychiatric aid (Shevchenko, 2011). The number of absolutely healthy children among modern first-graders is $4.3 \%$, which is half as much as at the end of the last century (8.7\%) (Golikova, 2010). Therefore, 
the task of improving the somatic and mental health of children in Russia, and in many other countries also, is of great priority.

In our view this problem cannot be resolved without analyzing children's perinatal development. The high prevalence of perinatal pathology is of particular concern. Normal pregnancy and childbirth without pathology have become an exception to the rule. For example, according to the Russian Ministry of Health, the percentage of normal births does not exceed 36.8\% (Golikova, 2010). Thus, we have to conclude that the development of most children today takes place against the backdrop of a lack of health. Meanwhile, the problem of how general state of health, and, in particular, perinatal disorder, affects the mental ontogeny, has not been adequately researched.

Perinatal pathology of nervous system (PPNS) is one of the most important causes of deviations of ontogenesis. "Adverse pregnancy and childbirth have often more detrimental effects on the nervous system and the human psyche than endoand exogenous factors in the postnatal period" (Palchik \& Shabalov, 2013, p.7). In the medical literature there are rather contradictory data on the prevalence of PPNS. According to different authors, it varies from 45 to $86 \%$, and the leading role in the genesis of PPNS belongs to hypoxia (Barashnev, 2001; Volodin, Medvedev, \& Rogatkin, 2001; Studenikin, Maslova, \& Khachatryan, 2003; Shabalov \& Tsveleva, 2002). Numerous maternal infectious and chronic diseases and various obstetric pathologies can cause intrauterine fetal hypoxia and asphyxia of newborns; in fact, asphyxia in childbirth is often a continuation of intrauterine fetal hypoxia (Badalyan, 2001; Volpe, 2008).

Depending on the severity of the hypoxia, the degree of asphyxia, adequacy of therapy, and other factors, perinatal nervous system damage can have a wide range of outcomes, ranging from favorable and severe. Severe hypoxic-ischemic encephalopathy leads to significant violations of ontogeny and diseases of the nervous system - cerebral palsy, epilepsy, mental retardation, and other severe maladies (Aicardi, 2013; Petrukhin, 2012; Palchik, 2013; Volpe, 2008). These diseases must be analyzed separately. However, in most cases (about 60\%) the prognosis for dealing with the consequences of perinatal CNS damage is favorable or relatively favorable: recovery or minimal brain dysfunction (Petrukhin, 2012; Studenikin et al., 2003).

Thus, investigation of the features of mental development of children with mild perinatal brain damages is necessary for the following reasons: Children with favorable outcomes of perinatal CNS injuries are in the majority; these children are the least studied; they are very seldom put under medical observation after 1 year old; they are not officially registered as disabled children and, so, the social environment's demands on them are quite tough; and there is a lack of rehabilitative programs for these children.

However, despite the urgency and practical importance of this problem, it has seldom been investigated. In the medical literature there are descriptions of a number of studies (Naeye \& Peters, 1987; Salova, 2009; Calvigioni \& Hurd, 2014; El Marroun, White, Verhulst, \& Tiemeier, 2014; Hebebrand \& Verhulst, 2014; Sayal, Heron, Draper, Alati, Lewis, Fraser,..., \& Gray, 2014; Tiesler \& Heinrich, 2014), proving the negative impact of intrauterine hypoxia, including of toxic origin, on 
the child's mental ontogenesis, even in cases of favorable outcome. Medical research cannot replace the psychological study of the issue. Usually, the medical studies focus on the neurological status of the children, and the psychological part of the research is reduced to one or two standardized tests. Very often in scientific medical research, there is a substitution of psychological terms and concepts. As a rule, medical researchers cannot conduct high-grade psychological and neuropsychological studies, just as psychologists cannot conduct competent medical investigations.

From our point of view, the method of neuropsychological syndrome analysis developed by A.R. Luria (Luria, 1966, 2000, 2002) is the most productive way of investigating the long-term consequences of perinatal CNS damage. Qualitative syndrome analysis, adopted by Russian child neuropsychology (Mikadze, 2008, 2011; Akhutina \& Pylaeva, 2008; Glozman, 2009, 2012), contributes to our understanding the mechanisms of this or that form of dysontogenesis, and allows us to determine the functional nature of the defect, as well as to take a new approach to developing corrective methods.

Previously, we used a neuropsychological analysis to study the influence of mild hypoxic PPNS on the mental ontogenesis (Sultanova, \& Ivanova, 2009, 2013, 2014; Sultanova, 2015, 2016). But our investigations were dedicated to preschool children, and the significant question is: What will happen to these children in the future? Perhaps some dysfunctions can be compensated for at school age, but could they instead be aggravated, negatively affecting mental ontogeny? Certainly, the older the child, the more difficult it is to see the impact of PPNS as the main factor causing an ontogenesis disorder: a lot of other external and internal factors have acted on the child. But the same factors influence the children without PPNS. The children in this study lived and developed in the same cultural, social and educational environment, which allows us to conduct a comparative study.

Thus, the objective of this study was to conduct neuropsychological analysis of the features of mental development of school-age children with mild hypoxicischemic perinatal CNS damage in their anamnesis.

\section{Methods}

Our research involved 62 children 10-12.5 years old (pre-teens) studying in comprehensive schools in Moscow; all the children were brought up in socially welloff families; all children wrote with their right hands - that is, there were no apparent left-handed people among them. The main group consisted of 42 neurologically healthy children who had hypoxic-ischemic encephalopathy of mild severity (the 1st degree) in their anamnesis; the Apgar scores (Apgar, 1953) in all these children were not less than 7 points (this information was taken from their medical records). The control (comparison) group consisted of 20 neurologically healthy children without indication of pathology of pregnancy and labor in their anamnesis.

We used the following methods: neuropsychological Luria tests adapted for children (Simernitskaya, 1991; Tsvetkova, 1998; Akhutina \& Pylaeva, 2003; Glozman, Potanina, \& Soboleva, 2006; Semenovich, 2002; Glozman, 2012); an interview of parents and teachers about the peculiarities of children's behavior; and analysis 
of electroencephalogram (EEG) reports. Each child's performance on the neuropsychological tests was evaluated by the standard for this type of diagnostic system: from 0 to 3, with 0 points being the perfect result, 3 points showing the most defect (a child cannot cope with the task, even after a prompt). To determine the reliability of the differences between the groups, we used the non-parametric MannWhitney statistical test (U criterion) and also the criterion $\varphi^{*}$ (the angular Fisher transform).

\section{Results}

Despite the apparently favorable outcome of perinatal damage of the nervous system (recovery: the children are officially recognized as healthy and are not observed by neurologists), the mental development of children of the main group had statistically significant differences from that of the control group. First of all, every child with PPNS had neurodynamic disorders. The neurodynamic disorders in the children studied were less pronounced than in the preschool children whom we investigated earlier. But they were observed in all the children of the main group (see Table 1 for numerical values) in the form of 1) a decrease in the ability to work; 2) the need for a prolonged preparation ("warm-up") period; 3 ) changes in the pace of activity; and 4) inertia. The pace of work for these children, as a rule, could be quite high, but only if the child did not work diligently, and performed tasks carelessly. For most children in the main group, the pace of work was significantly reduced if the child was trying to carry out tasks with high quality and attentiveness.

Table 1. Neurodynamic disorders in the children (number of children, $\%$ of all children in the group)

\begin{tabular}{|c|c|c|c|}
\hline Disorder & $\begin{array}{l}\text { The main } \\
\text { group, } \%\end{array}$ & $\begin{array}{l}\text { The control } \\
\text { group } \%\end{array}$ & $\begin{array}{c}\text { Statistical } \\
\text { significance } \\
\text { of differences }\end{array}$ \\
\hline Decrease in the ability to work & 84 & 25 & $p \leq 0.05$ \\
\hline Prolonged preparation (“warm-up”) period & 72 & 10 & $p \leq 0.01$ \\
\hline Changes in the pace of activity & 74.4 & 15 & $p \leq 0.05$ \\
\hline Inertia, including: & 79.2 & 15 & $p \leq 0.05$ \\
\hline $\begin{array}{l}\text { repetition of the previous finger's position in } \\
\text { the tests for kinesthetic praxis }\end{array}$ & 43.2 & 5 & $p \leq 0.05$ \\
\hline $\begin{array}{l}\text { difficulties in switching in tasks for dy- } \\
\text { namic praxis and assimilation of the motor } \\
\text { program }\end{array}$ & 79.2 & 15 & $p \leq 0.01$ \\
\hline $\begin{array}{l}\text { execution of previous instruction, or «jam- } \\
\text { ming» on the task execution algorithm }\end{array}$ & 69.6 & 10 & $p \leq 0.01$ \\
\hline «viscosity» of emotions & 67.2 & 10 & $p \leq 0.05$ \\
\hline total, those or other violations & 100 & 30 & $p \leq 0.01$ \\
\hline
\end{tabular}

Inertia manifested itself in the following phenomena. In the motor sphere it showed up in perseverations: for example, repetition of the previous finger position 
in the samples for kinesthetic praxis, repetition of the elements of the motor program, and the difficulty of switching in tasks for dynamic praxis, and «extra» letters or their elements in the writing. In the cognitive sphere it showed up as «jamming» on the previous instruction, or on the same way of performing the task.

For example, some children, after completing assignments for naming images, could not compose a story by picture, because they were just starting to identify the depicted objects; the children did this task correctly after the specialist pointed out that the task has changed, and it is necessary to describe what happens in the picture. In the emotional sphere the inertia showed in the "viscosity" of emotions, the continuation of an emotional response to the already completed situation. This was also reflected in parental reports, where parents noted their children's touchiness, or that "the child cannot calm down for a long time" after an event.

Due to fatigability, inertia, sluggishness, or hyperactivity, these children experience difficulties in communicating with other children and on lessons. This has a negative effect on the process of cognitive development, on the children's selfconcept and their social adaptation. It can be assumed that these neurodynamic features are directly related to the perinatal CNS damage, since the intrauterine period of development is especially important for the maturation of subcortical structures that support brain activation. The EEG reports of the children of the main group described dysfunctions of the subcortical and/or stem structures of various degrees of severity. This is consistent with the findings of medical research (Sokolova, 2004). Thus, neurodynamic disturbances which are associated with dysfunctions of the subcortical brain structures, can be the primary defect in children as the consequence of PPNS.

Another typical feature of children with PPNS was an insufficiency of voluntary regulation, or self-control. All children of the main group had this trait, but with differing severity (this is discussed below). In the control group, this condition was noted much more rarely (in 15\% of children). Goal-setting, programming, and monitoring - that is, functions that are controlled by the prefrontal brain (Luria, 2002; Khomskaya, 2005), the so-called "executive functions" (EF) - were late in developing in children of the main group. This was manifested in the process of neuropsychological research, in school, and at home.

In the process of the neuropsychological research the children were distracted and often acted impulsively; thus, the researcher was forced to repeat the instruction several times or call for careful execution of the assignment. For example, in the study of visual gnosis, children called the crossed-out image of the comb alike "saw", but when the researcher said "Pay close attention!" the children gave the correct answer. If the researcher could not intervene, the children did not cope. For example, in the study of verbal memory, children often reproduced the same word several times. As a result, their reduced self-control caused the deterioration of performance on the gnosis, attention, memory, and speech development tests. Teachers noted that these children are distracted and distract other children during their lessons, do not write down their homework, do not finish tasks, etc.; this reduced the child's progress in school.

According to the parents, these children often do not fulfill requests at home; they are very difficult to get to help with housework. Great difficulties arose around 
doing homework. Children could not "sit down for lessons" at home, preferring to play with gadgets or watch TV; they perform tasks carelessly and incompletely. It seems that these children can perform something productive only with the participation of an adult who is nearby; it's as if the adult is "fulfilling" the functions of the prefrontal parts of the brain.

R.A. Barkley (2000) identified such aspects of executive functions as:

- Volition, planning, purposive, goal-directed, or intentional action.

- Inhibition and resistance to distraction.

- Problem-solving and strategy development, selection, and monitoring.

- Flexible shifting of actions to meet task demands.

- Maintenance of persistence toward attaining a goal.

- Self-awareness across time.

Our research does not allow us to say anything about "self-awareness across time", but all the other five aspects of EF were inadequate to some extent in the children of the main group. A deficit of executive functions leads to negative consequences for the child's further development because these functions are "those capacities that enable a person to engage successfully in independent, purposive, self-serving behavior" (Lezak, 1995, p.42).

The insufficiency of executive functions may be associated with a lag of development of frontal lobes and connections between the frontal lobes and subcortical brain structures. Thus, according to the research data, two basic disorders underlie the deviations of mental ontogenesis of the children with PPNS: neurodynamic disorders and insufficiency of executive functions. We called this syndrome the "subcortical-frontal syndrome". Earlier, in the studies mentioned above, we observed similar disorders in preschool children. But in preschool children, neurodynamic disorders have come to the fore, while in school-age children, the deficit of executive functions is more pronounced.

In addition to the disorders described above, each child in the main group had a failure of at least one neuropsychological factor. That is, in general, a "mosaic picture" was observed, in which relatively preserved neuropsychological factors were combined with the insufficiency of others. Insufficiency of the following factors was noted most often: voluntary attention, verbal-auditory memory, kinetic and kinesthetic praxis, visual-spatial gnosis, and phonemic hearing. Auditory and tactile gnosis proved to be the most intact functions in the children of the main group. It should be noted that in tests for the localization of touch, children were not always accurate, but the same was observed in the control group. Statistically significant differences are presented in Table 2.

To our surprise, we found mistakes and synkinesis in the tests for kinesthetic praxis in many children in the main group. These mistakes were often not severe, but did not correspond to child's age. The children consistently changed their fingers in finding the right position; acted awkwardly; helped themselves by their other hand to fold their fingers to the right position; or were wrong and could not always correct the errors, even if the researcher pointed to them. Synkineses were observed only in children of the main group ( $60 \%$ of children); they were more manual-manual than manual-oral. 
Table 2. Statistically significant differences between groups in the performance of neuropsychological tests

\begin{tabular}{|c|c|c|c|}
\hline \multirow{2}{*}{ Insufficient function } & \multicolumn{2}{|c|}{ average score } & \multirow{2}{*}{$\begin{array}{l}\text { significance of } \\
\text { differences }\end{array}$} \\
\hline & main group & control group & \\
\hline Voluntary attention & 2.1 & 0.5 & $p \leq 0.01$ \\
\hline \multicolumn{4}{|l|}{ Motor functions: } \\
\hline kinesthetic praxis & 1.4 & 0 & $p \leq 0.05$ \\
\hline kinetic praxis & 2.3 & 0.6 & $p \leq 0.01$ \\
\hline including reciprocal hand coordination & 2.2 & 0.4 & $p \leq 0.01$ \\
\hline Visual-spatial gnosis & 2.1 & 0.8 & $p \leq 0.01$ \\
\hline Verbal-auditory memory & 1.4 & 0.5 & $p \leq 0.05$ \\
\hline Phonemic hearing & 1.8 & 0.6 & $p \leq 0.05$ \\
\hline
\end{tabular}

It should be noted that all the children studied were right-handed. But in the group of children with PPNS, "hidden" left-handedness was seen twice as often (see Table 3), and the dominance of the left eye and the left ear was also often observed. Children who had a leading left eye (that is, the dominance of the hand and the eye did not match) had difficulties in mastering writing skills sometimes to the point of dysgraphia. And we cannot ignore the fact that many children of the main group had hypermobility of the joints (possibly due to connective tissue dysplasia), as well as a variety of different obsessive movements.

Table 3. Different forms of left-side dominance in groups (number of children, \%).

\begin{tabular}{lcc}
\hline \multicolumn{1}{c}{ Form of left-side dominance } & Main group & Control group \\
\hline $\begin{array}{l}\text { children with latent left-handedness or children with } \\
\text { ambidexterity, who were «retrained» on the right hand: } \\
\text { the child writes with his right hand, but in activity often } \\
\text { uses his left hand, and Luria's tests show the dominance } \\
\text { of the left hand }\end{array}$ & $64 \%$ & $30 \%$ \\
$\begin{array}{l}\text { Domination of the left eye } \\
\text { Domination of the left ear }\end{array}$ & $48 \%$ & $35 \%$ \\
\hline
\end{tabular}

Kinetic praxis was naturally disturbed in children with PPNS in their anamnesis. We have already mentioned inertia, perseverations, and difficulties in retaining the motor program. A simplification of the program and a lack of smoothness of movements often were also observed in these children. In a graphomotor sample ("fence" with alternating elements $\Pi / /$ ) children very often introduced an extra "facilitating" element (this was the most common mistake). The task of "fist-palmedge" (to repeat the successive movements of the hand) was one of the most difficult for these children. Children in the control group also made mistakes in this task, but they were not as serious as those in the main group, and often the children corrected themselves. Children in the main group often just chaotically changed 
the poses of the hand, and only direct speech control could help. Children of the main group showed quite low results when performing a task for reciprocal hand coordination. Only $8.8 \%$ of these children did this task correctly; the rest made mistakes, moved their arms, carried out the movements slowly.

The children of both groups performed tasks for visual gnosis quite well. In the main group there were errors related to the impulsiveness of answering, and insufficient attention, but these errors were corrected by the children. Tests for visualspatial gnosis were difficult for children from both groups, but the children with PPNS consistently performed worse. In particular, a lot of mistakes and refusals to perform the task occurred in the test "clock with arrows". Perhaps this is due to the fact that children these days rarely use such clocks. However, there were many gross mistakes in the Piaget Bottles test (to draw the water level in a rotating bottle), although children today often deal with different drinks in bottles. Insufficient development of the spatial factor was manifested in other tests: kinesthetic praxis, spatial praxis, copying of figures. This insufficiency can be associated with a delay in the development of the occipital-parietal areas of the right hemisphere.

In the study of audio-verbal memory, significant results were obtained only in the test of memorizing ten words. The performance of the children in the main group demonstrated the following features: 1) a decrease in the results on the first attempt to recollect, which may be due to inertia, and a long indicative period; 2) a large number (up to 50\%) of errors, most of which were semantic substitutions (similar in meaning to the word) or substitutions by associative principle (for example, after the correct word "brother", the child spoke the wrong word "sister"); 3 ) frequent repetition of the same words when recollected; these errors are associated with a decrease in self-control; and 4) with delayed reproduction, children recollected fewer words (6.3 on average) than children of the control group (7.8 on average). Thus, the majority of children with PPNS had a tendency to decline in audio-verbal memory under the influence of two mechanisms: first, the weakness of trace formation, which may be associated with functional deficiency of the left temple area; and secondly, the reduction in the factor of voluntary control, which is provided by the prefrontal parts of the brain.

In children with PPNS in their anamnesis, certain distinctive features of speech development were also observed. These children made mistakes in naming objects, had difficulty formulating a compound sentence, and more often had dysarthria, dysgraphia and dyslexia, than those in the control group. But statistically significant differences were obtained only on phonemic hearing. The children of the main group made serious mistakes (the children in the control group sometimes confused the sounds "o" with "u"). Their insufficiency of phonemic hearing often led to misunderstanding the meaning of the word they heard and to mistakes in writing (dysgraphia).

Thus, according to our results of the study, left-hemispheric functions and interhemispheric interaction suffer to a greater degree in children with the consequences of PPNS. In general, it turned out that the development of the functions of the left hemisphere is more vulnerable to perinatal hypoxia than the development of right hemispheric functions.

We said above that the severity of violations of executive functions differed among the children of the main group. We divided the main group into two sub- 
groups, depending on the degree of these disorders. Children of subgroup 1 (16 persons, $38 \%$ of the main group, most of them girls) had pronounced neurodynamic disorders and little insufficiency of executive functions. Children of subgroup 2 (26 persons, 62\% from the main group, most of them boys) also had neurodynamic disorders, but the inadequacy of voluntary regulation of activity came to the fore.

Most children in the subgroup 1 had good school performance and social adaptation (see Table 4), but their quality of life was reduced. It took them a long time to do their homework, and they got "stuck" on negative experiences; they often had psychosomatic and neurotic reactions, increased anxiety, and decreased selfesteem. Deviant behavior was not observed in these children very often; deviant behavior manifested itself in the form of negativism, addictions (Internet addiction, game dependence, and overeating, etc.), absenteeism, and sometimes suicidal thoughts.

Table 4. Some characteristics of the selected subgroups

\begin{tabular}{ccccc}
\hline Subgroup & $\begin{array}{c}\text { Gender } \\
\text { composition }\end{array}$ & $\begin{array}{c}\text { School } \\
\text { performance, } \\
\text { average score } \\
\text { (max. 5) }\end{array}$ & $\begin{array}{c}\text { Corecution of tasks } \\
\text { on verbal-logical } \\
\text { thinking }\end{array}$ & $\begin{array}{c}\text { Deviant } \\
\text { behavior }\end{array}$ \\
\hline $\begin{array}{c}\text { Subgroup 1: } \\
\text { mild insufficiency of } \\
\text { executive functions }\end{array}$ & $\begin{array}{c}\text { about 75\% } \\
\text { of girls, and } \\
25 \% \text { of boys }\end{array}$ & 4.1 & $70 \%$ & $37.5 \%$ \\
$\begin{array}{c}\text { Subgroup 2: } \\
\text { pronounced insufficiency } \\
\text { of executive functions }\end{array}$ & $\begin{array}{l}\text { about 23\% } \\
\text { of girls, and } \\
77 \% \text { of boys }\end{array}$ & 3.3 & of children \\
of children & of children \\
\hline
\end{tabular}

In children of subgroup 2, the inadequacy of voluntary regulation becomes the main factor hampering productive activity and social adaptation. Children from subgroup 2 did worse in school, and they often broke the rules of the community. Indicators of verbal-logical intelligence were somewhat reduced in these children. These children had a lower school performance, and often deviant behavior was observed (verbal and physical aggression towards parents, teachers and peers, lying, absenteeism, theft, early tobacco smoking, and different addictions, etc.). These children are characterized by a lag in the formation of the ability to control emotional manifestations. Often they had a combination of aggressiveness towards their peers with negativism towards adults, especially when the adults were trying to regulate a child's activities. Also, the "sense of distance" in these children was violated. As a rule, they had a combination of increased emotional susceptibility and vulnerability about themselves, with a relatively low sensitivity to others, an insufficiency of empathy. These children had worse relationships with their peers and teachers, and their social adaptation was often disrupted. We can say that children from the subgroup 1 suffer from their condition while the children from subgroup 2 make the people around them suffer.

In our opinion, the features of children with PPNS we've described are due to two groups of factors: 
1. Functional insufficiency of various structures of the brain, which can be both primary (deficiency of subcortical structures) and secondary (mainly the impaired development of the left hemisphere).

2. Social factors. In most cases, the presence of the mild PPNS in a child is not sufficiently taken into account in the upbringing and education of the child. Parents, educators, and teachers make demands on the child as if he or she were a healthy child, demands which do not correspond to his capabilities. As a result, secondary disturbances of the emotional-personal sphere arise in the child, and often a quite pathological adaptation to the surrounding social environment appears.

\section{Conclusion}

Thus, the mental development of school-age children with a mild perinatal pathology of the nervous system in their anamnesis differs from the development of their peers. We can talk about the long-term consequences of the mild hypoxic perinatal damage of the nervous system. It is necessary to continue the study, although every year it is increasingly difficult to find children for the control group.

We investigated the effect of mild PPNS on ontogeny. However, we have seen cases when severe perinatal lesions of the nervous system did not lead to gross violations of the child's development. Analyzing such cases in a separate work would be necessary and interesting. Also, the impact of family upbringing, child-parent relations, and other social factors on the development of children with PPNS in their anamnesis would be interesting to investigate.

\section{Limitations}

The limitations of our research are primarily related to the small sample of children studied. In addition, all the children studied lived in urban conditions. Perhaps children living in rural areas would show slightly different results. Children with social deprivation, for example, who are not brought up in the family, but in orphanages, are also not investigated.

\section{References}

Aicardi, J. (2013). Zabolevaniya nervnoi sistemy u detei [Diseases of the Nervous System in Childhood]. Moscow: Izdatelstvo Panfilova; BINOM; Laboratoriya znanii.

Akhutina, T.V. \& Pylaeva, N.M. (2003). Diagnostika razvitiya zritel'no-verbal'nykh funktsii [Diagnostics of development of visual-verbal functions]. Moscow: Akademiya.

Akhutina, T.V. \& Pylaeva, N.M. (2008) Preodolenie trudnostei ucheniya: neiropsihologicheskii podhod [Overcoming the Learning Difficulties: Neuropsychological Approach]. Saint Petersburg: Piter.

Apgar, V. (1953). A proposal for a new method of evaluation of the newborn infant. Current researches in anesthesia \& analgesia, 32 (4), 260-267. https://doi.org/10.1213/00000539195301000-00041

Badalyan, L.O. (2001). Detskaya nevrologiya: Uchebnoe posobie. [Children's Neurology: A Training Manual]. Moscow: MEDpress-inform.

Barashnev, Yu.I. (2001). Perinatalnaya nevrologiya [Perinatal neurology]. Moscow: Triada-X. 
Barkley, R.A. (2000). Genetics of childhood disorders: XVII. ADHD, part 1: the executive functions and ADHD. Journal of the American Academy of Child \& Adolescent Psychiatry, 39(8), 1064-1070. https://doi.org/10.1097/00004583-200008000-00025

Bozhovich, L.I. (2008). Lichnost $i$ ee formirovanie $v$ detskom vozraste. [Personality and its formation in childhood]. Saint Petersburg: Piter.

Calvigioni, D. \& Hurd, Y.L. (2014). Neuronal substrates and functional consequences of prenatal cannabis exposure. European Child \& Adolescent Psychiatry, 23 (10), 931-941. https://doi. org/10.1007/s00787-014-0550-y

El Marroun, H., White, T., Verhulst, F. C., \& Tiemeier, H. (2014). Maternal use of antidepressant or anxiolytic medication during pregnancy and childhood neurodevelopmental outcomes: a systematic review. European Child \& Adolescent Psychiatry, 23 (10), 973-992. https://doi. org/10.1007/s00787-014-0558-3

Feldshtein, D.I. (2010). Prioritetnye napravleniya psikhologo-pedagogicheskikh issledovanii $v$ usloviyakh znachimykh izmenenii rebenka i situatsii ego razvitiya. Doklad na vyezdnom zasedanii Prezidiuma RAO v Nizhnem Novgorode 19-20 aprelya 2010 g. [Priority Trends in Psychological-Pedagogical Studies in the Conditions of Child's Significant Changes in the Situation of his Development. A report at the session of the RAE Board in Nizhniy Novgorod on April 19-20, 2010]. Moscow: MPSI; Voronezh: MODEK.

Glozman, Zh.M. (2009). Neiropsihologiya detskogo vozrasta. Uchebnoe posobie [Neuropsychology of childhood. Study Guide]. Moscow: Akademiya.

Glozman, Zh.M. (2012). O subektnosti lurievskoi neiropsihologii [Subject oriented Lurian neuropsychology]. The Moscow University Herald, Series 14, 2, 31-36.

Glozman, Zh.M., Potanina, A.Yu., \& Soboleva, A.E. (2006). Neiropsikhologicheskaya diagnostika $v$ doshkolnom vozraste [Neuropsychological diagnostics at preschool age]. Saint-Petersburg: Piter.

Golikova T.A. (2010). O vipolnenii v 2007-2009 godah meropriyatii plana realizacii Koncepcii demograficheskoi politiki Rossiiskoi Federacii na period do 2025 goda, napravlennih na uluchshenie sostoyaniya zdorovya jenschin, detei i podrostkov [About performance in 2007-2009 of the actions of the plan of implementation of the Concept of population policy of the Russian Federation until 2025 directed to improvement of the state of health of women, children and adolescents]. Handbook of a paramedic and midwife, 5, 8-14.

Hebebrand, J. \& Verhulst, F. (2014). Prenatal risk factors and postnatal central nervous system function. European Child \& Adolescent Psychiatry, 23 (10), 857-861. https://doi.org/10.1007/ s00787-014-0617-9

Khomskaya, E.D. (2005). Neiropsihologiya. Uchebnik [Neuropsychology. Textbook]. 4th edition. Saint Petersburg: Piter.

Lezak, M.D. (1995). Neuropsychological assessment. New York: Oxford University Press.

Luria, A.R. (1966). Human brain and psychological processes. N.Y.: Harper \& Row.

Luria, A.R. (2000). Vysshie korkovie funkcii cheloveka $i$ ih narushenie pri lokalnih porajeniyah mozga [Higher cortical functions of man and their disturbances in local brain lesions]. 3rd ed. Moscow: Academ. project.

Luria, A.R. (2002). Osnovy neiropsihologii. Uchebnoe posobie. [Fundamentals of neuropsychology. Tutorial]. Moscow: Akademiya.

Mikadze, Y.V. (2011). Methodology of neuropsychological assessment: qualitative (metasyndromal analysis of cognitive deficit structure) and quantitative (psychometricestimate) aspects. Psychology in Russia: State of the Art, 4, 261-267. https://doi.org/10.11621/ pir.2011.0015

Mikadze, Yu.V. (2008). Nejropsyhologia detskogo vozrasta [Developmental neuropsychology]. Saint Petersburg: Piter. 
Naeye, R.L. \& Peters, E.C. (1987). Antenatal hypoxia and low IQ values. American Journal of Diseases of Children, 141(1), 50-54.

Palchik, A.B. (2013). Lekcii po nevrologii razvitiya. [Lectures on neurology of development]. 2nd ed. Moscow: MEDpress-inform.

Palchik, A.B. \& Shabalov, N.P. (2013). Gipoksicheski-ishemicheskaya entsefalopatiya novorozhdennykh [Hypoxic-ischemic encephalopathy of newborns] (4d ed.). Moscow, MEDpressinform.

Petrukhin, A.S. (2012). Detskaya nevrologiya: Uchebnik [Pediatric neurology: Textbook]. Moscow: GEOTAR-Media.

Salova, M.N. (2009). Sostoyanie zdorovya detei 9-11 let s posledstviyami perinatalnyh gipoksicheskih porajenii centralnoi nervnoi sistemi s uchetom tipa ih psihosomaticheskoi konstitucii [The state of health of children aged 9 to 11 years with the consequences of perinatal hypoxic lesions of the central nervous system, taking into account the type of their psychosomatic constitution]. PhD thesis. Ivanovo: Ivanovo State Medical Academy.

Sayal, K., Heron, J., Draper, E., Alati, R., Lewis, S.J., Fraser, R., ..., \& Gray, R. (2014). Prenatal exposure to binge pattern of alcohol consumption: mental health and learning outcomes at age 11. European Child \& Adolescent Psychiatry, 23 (10), 891-899. https://doi.org/10.1007/ s00787-014-0599-7

Semenovich, A.V. (2002) Neiropsikhologicheskaya diagnostika i korrektsiya $v$ detskom vozraste [Neuropsychological diagnostics and correction in childhood]. Moscow: Akademiya.

Shabalov, N.P. \& Tsveleva, Yu.V. (2002). Osnovy perinatologii [Fundamentals of Perinatology]. Moscow, MEDpress-inform.

Shevchenko, Yu.S. (2011). Detskaya i podrostkovaya psikhiatriya: Klinicheskie lektsii dlya professionalov [Child and Adolescent Psychiatry: Clinical lectures for Professionals]. Moscow: Meditsinskoe informatsionnoe agentstvo.

Simernitskaya, E.G. (1991). Metodika ekspress-diagnostiki "Luriya-90" [Method of rapid diagnosis "Luria-90"]. Moscow: Obshchestvo "Znanie".

Sokolova, M.G. (2004). Kliniko-patogeneticheskaya diagnostika nevrologicheskih rasstroistv u podrostkov s rezidualnym porajeniem centralnoi nervnoi sistemi perinatalnogo geneza [Clinical and pathogenetic diagnosis of neurological disorders in adolescents with residual lesions of the central nervous system of perinatal origin]. PhD thesis. Saint Petersburg St. Petersburg: Medical Academy of Postgraduate Education.

Studenikin, V.M., Maslova, O.I., \& Khachatryan, L.G. (2003). Perinatalnye porazheniya nervnoi sistemy i ikh iskhody [Perinatal damages of the nervous system and their outcomes]. Doktor. Ru - zhurnal sovremennoi meditsiny. Retrieved from http://medprom.ru/medprom/39128

Sultanova, A.S. (2015). Influence of a mild perinatal pathology of the nervous system on mental ontogenesis: neuropsychological analysis. Medical psychology in Russia, 5 (34). Retrieved from: http://www.mprj.ru/archiv_global/2015_5_34/nomer04.php

Sultanova, A. (2016). Long-term consequences of a mild perinatal pathology of the nervous system for mental ontogenesis. International Journal of Psychology, 51, S1, 118.

Sultanova, A. \& Ivanova, I. (2009). Influence of perinatal pathology of central nervous system on mental health of preschool children. Psychiatriki, 20, 99-100.

Sultanova, A. \& Ivanova, I. (2010). The features of a social situation of development of children under modern Russian conditions. In International Symposium Situating Childhood \& Child Development: Socio-cultural Approaches and Educational Interventions. Potsdam, Germany: Department for Teacher Training University of Potsdam \& International Society for Cultural and Activity Research (26-27). 
Sultanova, A. \& Ivanova, I. (2014). Application of Vygotsky-Luria's doctrine to study of the features of mental development in preschool children with mild perinatal brain pathology. In Estoril Vigotsky Conference 2014 (p. 10). Lisbon, Portugal: Lev Vygotsky Institute.

Sultanova, A. \& Ivanova, I. (2013). Features of Mental Development of Children with Mild Perinatal Brain Pathology. In Daphne Halkias (Eds.). Psychology and the Search for Certainty in Everyday Life (pp. 217-227). Athens, Greece: Athens Institute for Education and Research.

Tiesler, C.M.T. \& Heinrich, J. (2014). Prenatal nicotine exposure and child behavioural problems. European Child \& Adolescent Psychiatry, 23 (10), 913-929. https://doi.org/10.1007/ s00787-014-0615-y

Tsvetkova, L.S. (1998). Metodika neiropsikhologicheskoi diagnostiki detei [Method of neuropsychological diagnostics of children]. Moscow: Rossiiskoe pedagogicheskoe agentstvo, Kogito-tsentr.

Volodin, N.N., Medvedev, M.I., \& Rogatkin, S.O. (2001). Perinatalnaya encefalopatiya i ee posledstviya - diskussionnie voprosi semiotiki, rannei diagnostiki i terapii [Perinatal encephalopathy and its consequences - debatable questions of semiotics, early diagnosis and therapy]. Russian Pediatric Journal, 1, 4-8.

Volpe, J.J. (2008). Neurology of the newborn (5th ed.). Philadelphia: Elsevier.

Vygotsky, L.S. (1984). Sobranie sochinenii: v 6-ti t. T. 4. Detskaya psihologiya [Collected works: In 6 volumes. Vol. 4. Child Psychology]. Moscow: Pedagogika.

Original manuscript received October 1, 2017

Revised manuscript accepted January 22, 2018

First published online April 30, 2018 